\title{
A follow-up investigation of the Malta-Project
}

\author{
W H JOPLING,* MARIAN J RIDLEY, $\dagger$ \\ E BONNICI \& \& DEPASQUALE $\ddagger$ \\ ${ }^{*}$ WHO short-term consultant; $\dagger$ Hospital for Tropical Diseases, \\ London; $\ddagger$ St Luke’s Hospital, G'Mangia, Malta
}

Accepted for publication 6 January 1984

\begin{abstract}
Summary A report is presented of a follow-up examination of 116 multibacillary leprosy patients who had received multidrug therapy (MDT) as part of a leprosy eradication programme known as the Malta-Project, inaugurated in 1972. Length of treatment varied between 5 and 89 months, and side-effects were mostly mild. No signs of clinical relapse were found at follow-up, and 36 patients had positive skin smears; 26 had granular bacilli alone, and 10 had scanty 'solids'. It is proposed that these 'solids' are 'persisters', and their significance will be known after long-term follow-up of these 10 patients.
\end{abstract}

\section{Introduction}

The objective of this follow-up investigation, carried out in April 1983, was to examine the bacilliferous patients who had been given multidrug therapy (MDT) in Malta since 1972. The particular objectives were the following: 1, to look for signs of clinical relapse; 2, to discover if any leprosy bacilli, whether granular or solid-staining, were present in skin smears; and 3, to study the incidence of side-effects.

Professor E Freerksen's design of the Malta-Project ${ }^{1}$ was to treat by MDT all leprosy patients whose names appeared on the registration lists of the Ministry of Health, and similarly to treat all new patients diagnosed in subsequent years, with the objective of eradicating leprosy from Malta by rapidly rendering the patients non-infectious. It should be noted that he never intended that this should be looked upon as therapeutic research:

'The Malta-Project is not meant to be a trial with the objective to assess anti-leprosy drugs, but an eradication programme which is exclusively based on antimycobacterial chemotherapy.' 
Two-hundred-and-six patients began MDT in June or July 1972 when the Malta-Project was launched, and included paucibacillary and multibacillary cases. The majority had received monotherapy with dapsone for varying periods measured in years. Chemotherapy in all cases consisted of 4 drugs: rifampicin, dapsone, prothionamide, and isoniazid, the last 3 being incorporated in a tablet named Isoprodian. Patients weighing $50 \mathrm{~kg}$ or more received $600 \mathrm{mg}$ of rifampicin and 2 tablets of Isoprodian daily for 6 days/week, each tablet consisting of $50 \mathrm{mg}$ of dapsone, $175 \mathrm{mg}$ of prothionamide, and $175 \mathrm{mg}$ of isoniazid, and a reduction in dosage was made for those weighing less than $50 \mathrm{~kg}$. The majority of patients began MDT in June or July 1972, the minority subsequently. Length of MDT depended on the original clinical, bacterial, and histological assessment of each patient, taken in conjunction with response to treatment; the shortest course was 5 months (a BL patient who had previously been treated with dapsone for 6 years), and the longest was 89 months (a new and hyperactive LL patient).

\section{Materials and methods}

There were 128 patients listed as multibacillary who were available for examination in April 1983, 75 males and 53 females, their ages ranging from 20 to 82 years, with a mean of 55 years. Because of the limited time available, clinical examinations were shared as follows: 83 patients were examined by WHJ, and examination of the remaining 45 was shared between EB and GD. Six skin smears were taken by WHJ from each of the 128 patients, and the following system was strictly followed:

Smear no.1 from the right earlobe.

Smear no.2 from the left earlobe.

Smear no. 3 from the right mid-finger (dorsum of 1st phalanx).

Smear no.4 from the left mid-finger (dorsum of 1st phalanx).

Smear no. 5 from the right upper arm (just above elbow).

Smear no.6 from the left upper arm (just above elbow).

The urine of every patient was examined for protein and sugar, and a small sample was sent to Dr H. Huikeshoven, Amsterdam, to be tested for the presence of dapsone by his ELISA method. ${ }^{2}$ Medical records were studied and side-effects of treatment were noted.

\section{Results}

Findings in 6 of the 128 patients were excluded from this report because a study of case records showed that they were originally classified as BT cases. This left a 
total of 122 multibacillary patients, and from this number a further 6 were excluded as 2 had not completed MDT at the time of the investigation, and 4 because Dr Huikeshoven could not give an unequivocal assurance regarding absence of dapsone in their urine samples. Urine specimens from the 2 patients who had not completed MDT were found to be strongly positive. All other specimens were negative for dapsone.

This left 116 multibacillary patients for clinical and bacterial follow-up. The group consisted of 70 males and 46 females, their ages ranging from 22 to 82 years with a mean of 56 . At the time of diagnosis 88 patients had been classified as LL,

Table 1. Details of 26 multibacillary leprosy patients with only granular bacilli in follow-up skin smears in April 1983

\begin{tabular}{|c|c|c|c|c|c|}
\hline Patient & $\begin{array}{l}\text { DDS prior } \\
\text { to MDT } \\
\text { (years) }\end{array}$ & MDT began & $\begin{array}{c}\text { MDT } \\
\text { (months) }\end{array}$ & $\begin{array}{c}\text { Months since } \\
\text { beginning MDT }\end{array}$ & $\begin{array}{l}\text { Months since } \\
\text { ending MDT }\end{array}$ \\
\hline $1 \mathrm{LL}$ & 3 & June 1972 & $56^{*}$ & 130 & 74 \\
\hline $2 \mathrm{BL}$ & 7 & June 1972 & 33 & 130 & 97 \\
\hline $3 \mathrm{LL}$ & 24 & June 1972 & $30^{*}$ & 130 & 100 \\
\hline $4 \mathrm{LL}$ & 19 & June 1972 & $29 *$ & 130 & 101 \\
\hline $5 \mathrm{LL}$ & 11 & June 1972 & $23^{*}$ & 130 & 107 \\
\hline $6 \mathrm{LL}$ & 19 & June 1972 & $23^{*}$ & 130 & 107 \\
\hline $7 \mathrm{LL}$ & 17 & June 1972 & 22 & 130 & 108 \\
\hline $8 \mathrm{LL}$ & 5 & June 1972 & $22 *$ & 130 & 108 \\
\hline $9 \mathrm{LL}$ & 29 & June 1972 & 21 & 130 & 109 \\
\hline $10 \mathrm{LL}$ & 20 & June 1972 & 21 & 130 & 109 \\
\hline $11 \mathrm{BL}$ & 5 & June 1972 & $20^{*}$ & 130 & 110 \\
\hline $12 \mathrm{LL}$ & 19 & June 1972 & $20^{*}$ & 130 & 110 \\
\hline $13 \mathrm{LL}$ & 5 & June 1972 & $20^{*}$ & 130 & 110 \\
\hline $14 \mathrm{LL}$ & 26 & July 1972 & $80^{*}$ & 129 & 49 \\
\hline $15 \mathrm{LL}$ & 21 & July 1972 & 26 & 129 & 103 \\
\hline $16 \mathrm{LL}$ & 14 & July 1972 & $26^{*}$ & 129 & 103 \\
\hline $17 \mathrm{LL}$ & 23 & Sept. 1972 & 12 & 127 & 115 \\
\hline $18 \mathrm{LL}$ & 17 & Nov. 1972 & $17^{*}$ & 125 & 108 \\
\hline $19 \mathrm{LL}$ & 15 & Apr. 1973 & $71 *$ & 120 & 49 \\
\hline $20 \mathrm{LL}$ & 1 & Feb. 1974 & $48^{*}$ & 110 & 62 \\
\hline $21 \mathrm{BL}$ & 0 & July 1974 & $16^{*}$ & 105 & 89 \\
\hline $22 \mathrm{LL}$ & 2 & Mar. 1978 & $26^{*}$ & 61 & 35 \\
\hline $23 \mathrm{LL}$ & 3 & Aug. 1978 & $21^{*}$ & 56 & 35 \\
\hline $24 \mathrm{LL}$ & 0 & June 1979 & $11^{*}$ & 46 & 35 \\
\hline $25 \mathrm{LL}$ & 0 & Mar. 1980 & $32^{*}$ & 37 & 5 \\
\hline $26 \mathrm{LL}$ & 0 & May 1982 & $\begin{array}{c}8 \\
\text { (interrupted) }\end{array}$ & 11 & 3 \\
\hline
\end{tabular}

$\mathrm{LL}=$ Lepromatous. $\mathrm{BL}=$ Borderline-lepromatous. ${ }^{*} \mathrm{Granular}$ bacilli present at end of MDT. 
22 as BL, and 6 as BB. However, all 122 patients are included in the study of side-effects of treatment.

\section{Clinical findings in 116 patients}

No signs of clinical relapse were found.

\section{Bacterial findings in 116 patients}

Examination of skin smears was carried out by MJR at the Hospital for Tropical Diseases, and 36 were found to have positive smears (31\%); 26 had only granular bacilli (Table 1), 3 had a combination of scanty solid-staining and granular

Table 2. Details of 10 multibacillary leprosy patients with solid-staining bacilli in follow-up skin smears in April 1983

\begin{tabular}{|c|c|c|c|c|c|}
\hline Patient & $\begin{array}{l}\text { DDS prior } \\
\text { to MDT } \\
\text { (years) }\end{array}$ & $\begin{array}{l}\text { MDT } \\
\text { (months) }\end{array}$ & $\begin{array}{l}\text { Months since } \\
\text { beginning MDT }\end{array}$ & $\begin{array}{l}\text { Months since } \\
\text { ending MDT }\end{array}$ & $\begin{array}{l}\text { Findings in skin smears, } \\
\text { April } 1983\end{array}$ \\
\hline $1 \mathrm{LL}$ & 2 & $74^{*}$ & 130 & 56 & $\begin{array}{l}\text { Scanty 'solids' in left upper arm. } \\
\text { The other } 5 \text { smears are negative. }\end{array}$ \\
\hline $2 \mathrm{LL}$ & 0 & $72^{*}$ & 121 & 49 & $\begin{array}{l}\text { One 'solid' in right mid-finger. } \\
\text { The other } 5 \text { smears are negative. }\end{array}$ \\
\hline $3 \mathrm{LL}$ & 0 & $42^{*}$ & 83 & 41 & $\begin{array}{l}\text { Scanty 'solids' in left mid-finger, } \\
\text { and a few granular bacilli in } \\
\text { right upper arm. } \\
\text { The other } 4 \text { smears are negative. }\end{array}$ \\
\hline $4 \mathrm{LL}$ & 19 & $41^{*}$ & 130 & 89 & $\begin{array}{l}\text { Scanty 'solids' and granular } \\
\text { bacilli in right mid-finger and } \\
\text { in right earlobe. } \\
\text { The other } 4 \text { smears are negative. }\end{array}$ \\
\hline $5 \mathrm{BL}$ & 16 & $24^{*}$ & 130 & 106 & $\begin{array}{l}\text { One 'solid' in right mid-finger. } \\
\text { The other } 5 \text { smears are negative. }\end{array}$ \\
\hline $6 \mathrm{LL}$ & 3 & $23^{*}$ & 130 & 107 & $\begin{array}{l}\text { One 'solid' in right mid-finger. } \\
\text { The other } 5 \text { smears are negative. }\end{array}$ \\
\hline $7 \mathrm{BL}$ & 0 & $21^{*}$ & 56 & 35 & $\begin{array}{l}\text { Scanty 'solids' in left mid-finger. } \\
\text { The other } 5 \text { smears are negative. }\end{array}$ \\
\hline $8 \mathrm{BL}$ & 12 & 20 & 130 & 110 & $\begin{array}{l}\text { Scanty 'solids' in left mid-finger. } \\
\text { The other } 5 \text { smears are negative. }\end{array}$ \\
\hline $9 \mathrm{BL}$ & 0 & 20 & 94 & 74 & $\begin{array}{l}\text { One 'solid' in left mid-finger. } \\
\text { The other } 5 \text { smears are negative. }\end{array}$ \\
\hline $10 \mathrm{LL}$ & 0 & $14^{*}$ & 45 & 31 & $\begin{array}{l}\text { Scanty 'solids' in right upper arm, } \\
\text { and granular bacilli in all } 6 \text { smears. }\end{array}$ \\
\hline
\end{tabular}

Notes. $\mathrm{LL}=$ lepromatous. $\mathrm{BL}=$ borderline-lepromatous. ${ }^{*}$ Granular bacilli present at end of MDT. 
bacilli, and 7 had only scanty solid-staining bacilli (Table 2). In the 10 patients with solid-staining bacilli, one or other finger was positive in 8 , and in 7 the fingers were the only sites containing solid-staining organisms (Table 2).

\section{Side-effects of MDT in 122 patients}

Although a number of patients had died since the launching of the Project in 1972, no deaths were attributable to treatment. One patient developed clinical jaundice 8 months after beginning treatment, but was able to continue after an interval of 4 months. Other effects were mild and included gastro-intestinal upset in 31, glossitis in 16, dizziness in 9, nerve pain in 3 , joint pain in 1 , and abnormal liver function tests were noted in a patient who had begun MDT in May 1982, causing treatment to be interrupted; but it should be noted that LFT's were not routinely recorded prior to 1978. ENL occurred in 52 patients $(42.6 \%)$. Bouts of ENL were usually of short duration, and more prolonged bouts were satisfactorily controlled by thalidomide so that treatment was not interrupted. Necrotic ENL was not encountered. Upgrading (reversal) reactions were seen in 2 patients.

\section{Other findings in 122 patients}

Routine urine tests revealed protein in 7 and sugar in 8 . In addition, one specimen contained protein and sugar. The finding of glycosuria in 9 patients reflects the high incidence of diabetes in Malta, and the majority of these 9 patients were known diabetics.

\section{Discussion}

Clinicians who are instituting MDT for the first time, and are anxious about possible serious side-effects, will be encouraged by these findings, especially as 4 drugs were used in the Malta-Project as against 3 recommended in 1982 by the WHO Study Group. ${ }^{3}$ These 3 drugs are rifampicin, dapsone, and clofazimine, with rifampicin given on a monthly regimen (supervised), with the possible alternative of substituting prothionamide (or ethionamide) for clofazimine in patients with light skins who find skin pigmentation intolerable. Freerksen included isoniazid in his multidrug regimen for 2 reasons: firstly, because he credits it with a potentiating effect on the other 3 drugs, and secondly to have a combination of drugs suitable for treating tuberculosis as well as leprosy. ${ }^{4}$ This combination was well tolerated in the group under consideration; although ENL was observed in $42.6 \%$, and gastro-intestinal upset in $25.4 \%$, these and rarer side-effects did not cause any interruption of treatment except for the 2 patients who showed signs of liver toxicity.

No signs of clinical relapse were noted, and examination of skin smears 
showed that granular bacilli alone (i.e. without solid-staining bacilli) were found in 26 patients $(22.4 \%)$; 19 of these 26 patients had granular bacilli even though 10 years or more had elapsed since the time of beginning MDT, 4 or more years had elapsed since stopping, and 2 patients had received treatment for 6-7 years (Table 1). This finding raises doubts about the practicality of the recommendation of the WHO Study Group that, where possible, MDT should be continued up to bacterial negativity, namely, up to the time when the last granular bacillus has disappeared from follow-up skin smears, for this may necessitate continuing treatment for up to 10 years. After all, removing dead bacilli from the tissues is not a function of chemotherapy but is a function of macrophages, and macrophages in lepromatous leprosy are peculiarly ineffective at this task.

Table 2 shows that scanty 'solids' were found in 10 patients out of $116(8.6 \%)$, yet 2 of them had been treated for 6 years ( 72 and 74 months respectively); in 3 there were granular forms in addition, but in 7 the solid-staining forms were the only ones found. It is of special interest that one or other finger was positive for 'solids' in 8 of these 10 patients, and in 7 of them the fingers were the only positive sites. This finding gives strong support to the original work at the Hospital for Tropical Diseases which showed that in long-treated LL patients the fingers are the most likely sites in which to find them, ${ }^{5,6}$ and confirms that follow-up skin smears in multibacillary leprosy should always include two from fingers. We suggest that these 'solids' represent 'persisters' (drug-sensitive, dormant bacilli), and that the generous supply of dermal nerves in fingers increases the likelihood that bacilli sheltering within them may be extracted by the tip of the scalpel blade. Freerksen has decided that these 10 patients will not be retreated but will be closely observed over future years to see if any multiplication and dissemination of leprosy bacilli takes place, and this will prove an important piece of clinical research.

It is important that an answer is found to the question of how long MDT should be continued. The expense of continuing up to bacterial negativity could be justified if it could be shown that the likelihood of eliminating 'persisters' would thereby be increased, and it is to be hoped that future clinical research will provide an answer to this question. The findings in this follow-up investigation suggest that in many cases it is unnecessary to continue MDT up to bacterial negativity, and stopping treatment at a stage when granular bacilli are still present in skin smears can be justified, for out of 116 patients there were $67(57.7 \%)$ who had granular bacilli when MDT ceased, yet no 'solids' were found in April 1983; 48 of these 67 patients had completely negative skin smears at follow-up, and 19 had only granular bacilli. Length of treatment in these 67 patients averaged 30 months. Further experience with MDT may show that if 'persisters' are not killed after 2-3 years of treatment, no useful purpose will be served by continuing up to bacterial negativity. The important proviso is, however, that a programme of follow-up examinations must be strictly followed. 


\section{Acknowledgements}

We are grateful to Professor E Freerksen for encouraging this follow-up investigation and for putting case records at our disposal, and to the Ministry of Health in Valletta, Malta, for permission to publish our findings.

\section{References}

${ }^{1}$ Freerksen E, Rosenfeld M. Leprosy eradication project of Malta. Chemotherapy 1977; 23: $356-86$.

${ }^{2}$ Huikeshoven H, de Wit M, Soeters A, Landheer JE, Leiker DL. ELISA inhibition technique for the demonstration of sulphones in body fluids. Lepr. Rev. 1981; 52: 11-8.

3 WHO Study Group. Chemotherapy of Leprosy for Control Programmes. Technical Report Series No. 657, 1982.

${ }^{4}$ Freerksen E, Rosenfeld M. Leprosy-Tuberculosis Eradication. Amsterdam: Excerpta Medica, 1980.

5 Ridley MJ, Jopling WH, Ridley DS. Acid-fast bacilli in the fingers of long-treated lepromatous patients. Lepr. Rev. 1976; 47: 93-6.

6 Jopling WH, Rees RJW, Ridley DS, Ridley MJ, Samuel NM. The fingers as sites of leprosy bacilli in pre-relapse patients. Lepr. Rev. 1979; 50: 289-92. 